Mediscope

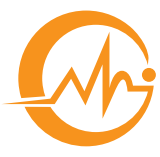

The Journal of GMC

\title{
Study on serum zinc and copper levels in pulmonary tuberculosis patients before starting Directly Observed Treatment, Short-course
}

\author{
*PS Biswas ${ }^{1}$, AMM Al Amin², SD Haque ${ }^{3}$
}

\begin{abstract}
Background: Tuberculosis is a major public health concern throughout the world including Bangladesh. The prevalence of tuberculosis (TB) is increasing day by day. Around one-third of world population is infected with $M$. tuberculosis. Still pulmonary tuberculosis (PTB) remains one of the important causes of mortality throughout the world with economic burden. Objective: To evaluate levels of the serum zinc and serum copper in smear positive PTB patients before starting Directly Observed Treatment, Short-course (DOTs) therapy. Methods: This was a cross-sectional type of observational study. A total of 100 subjects were included in this study. Among them 50 were smear positive PTB patients denoted as case group and 50 were apparently healthy individuals denoted as control group. Biochemical tests were carried out in the department of biochemistry of Mymensingh Medical College, Mymensingh. All the statistical analyses were performed by using SPSS version 21. Results were evaluated by using Student's t-test. Results: After careful evaluation there was significant decrease in serum zinc level along with significant increase in serum copper level among the case group when compared with the control group. The mean values of serum zinc level were $93.96 \pm 10.04 \mu \mathrm{g} / \mathrm{dl}$ and $72.84 \pm 7.73$ $\mu \mathrm{g} / \mathrm{dl}$ in control and case group respectively. Serum zinc level decreased significantly $(p<0.001)$ in PTB patients. The mean values of serum copper were $111.81 \pm 21.26 \mu \mathrm{g} / \mathrm{dl}$ and $125.99 \pm 27.93$ $\mu \mathrm{g} / \mathrm{dl}$ in control and case group respectively. There was significant $(p<0.001)$ rise of serum copper level in PTB patients.
\end{abstract}

Keywords: Smear positive pulmonary tuberculosis, Serum zinc, Serum copper, BMI.

\section{Introduction}

Tuberculosis, a major public health concern throughout the world, is caused by mycobacterium and its different variants and most commonly caused by Mycobacterium tuberculosis (MTB). TB causes chronic pulmonary diseases and also some other systemic diseases. ${ }^{1}$ TB is also considered as the second most common causes of death due to any infectious disease globally. ${ }^{2}$ The course of infection may be acute or chronic. It is a potentially fatal disease that can affect almost any part but commonly the lungs. ${ }^{3}$ TB is mostly associated with poverty, poor hygiene, malnutrition and HIV infection that cause immunosuppression. There were 8.7 million new cases and 1.4 million deaths. ${ }^{4}$ One-third

1. Dr. Prithwy Shankar Biswas, Assistant Professor, Department of Biochemistry, Gazi Medical College, Khulna. 
of the world population is latently infected with MTB and around 10\% immunocompetent individuals have a chance of reactivation while up to $90 \%$ chance of reactivation in case of immunocompromized individuals. ${ }^{5}$

Bangladesh is a country with higher rate of migration from village to town and that population faces poverty, overcrowding and poorly ventilated living and working condition. ${ }^{6}$ According to WHO global report 2016, in Bangladesh 362,000 case were detected annually with a death number of about 73,000 due to TB or TB associated complications. ${ }^{7}$

Micronutrients are very important for maintaining normal body function. The deficiency of micronutrients like Zinc leads to impaired immunity and thereby increases the susceptibility to infection such as TB. ${ }^{8}$ Zinc plays a vital role for maintaining both cellular and humoral defense system. Deficiency of zinc causes imbalance between Th-1 and Th-2 function. ${ }^{9}$ Copper is also an important trace element. It has role to attach and accept electron that helps in removing free radicals. ${ }^{10}$ The oxidative potential of copper causes oxidative damage to biological system.

Methodology

Study design: This was a cross-sectional study carried out in the department of biochemistry, Mymensingh Medical College in cooperation with Medicine outpatient department of Mymensingh Medical College Hospital and DOTs centers of BRAC and DAMIEN foundation (a non-government organization) during the period of July 2016 to June 2017.

Sample size: A total of 100 subjects were included among which control group (group-I) consisted 50 apparently healthy people from different age, sex and socioeconomic status. Case group (group-II) was 50 smear positive PTB patients before starting DOTS therapy of different age, sex and socioeconomic status. All the subjects were included with specific exclusion and inclusion criteria.

Sampling technique: Purposive (non-random) sampling technique was used for this study.
Data collection method: Permission was taken from concerned authorities. All the subjects of this study were informed and included after their consents. Data were collected through preformed data collection sheets (Questionnaire).

Collection of samples: With all aseptic precaution $5 \mathrm{ml}$ of venous blood was collected from median antecubital vein of the subjects. After clot formation and centrifugation serum was collected.

\section{Laboratory investigations:}

- Estimation of serum Zinc: serum zinc was determined by colorimetric method with 2- (5-Brom-2- pridylazu) -5-[N-propy-N-(3-sulfopropyl) amino] phenol. ${ }^{12}$

- Estimation of serum Copper: serum copper was determined by colorimetric method with the 3,5-DiBr-PAESA stain. ${ }^{13}$

Data analysis: All the data were analyzed by SPSS version 21 for windows. Body mass index (BMI) was measured by using standard formula: $\mathrm{BMl}=$ weight $(\mathrm{Kg}) /$ height $\left(\mathrm{m}^{2}\right)$. Data were expressed in mean \pm SD and statistical significance of difference among the groups were calculated by using Student's unpaired t-test. At the level of $95 \%$ confidence limit, $p$ $<0.05$ was considered as statistically significant and $p>0.05$ as not significant.

\section{Results}

A total of 100 subjects participated who were classified into a control group (group-I) of 50 apparently healthy individuals and a case group (group-II) of 50 smear-positive PTB patients before starting DOTs therapy.

Age and sex distribution of the subjects: The age of the subjects ranged from 18 to 65 years, with a mean age of $38.7 \pm 5.47$ for group I (control) and $38.9 \pm 5.50$ for group II (case). Maximum patients of smear positive pulmonary tuberculosis belonged to 26-35 years age group. The analysis shows that the 
differences in mean value of age between two groups were statistically not significant. The level of significance was 0.967 ( $p>0.05)$. The age distribution of the subjects is presented in Table 01.

Table 01: Age distribution of study subjects

\begin{tabular}{|c|c|c|c|c|c|}
\hline \multirow{3}{*}{$\begin{array}{l}\text { Age (in } \\
\text { years) }\end{array}$} & \multicolumn{4}{|c|}{ Groups } & p-value \\
\hline & \multicolumn{2}{|c|}{ Control group (I) } & \multicolumn{2}{|c|}{ Case group (II) } & \multirow[t]{9}{*}{$0.967^{\mathrm{ns}}$} \\
\hline & Count & $\%$ & Count & $\%$ & \\
\hline $16-25$ & 05 & 10.00 & 08 & 16.00 & \\
\hline $26-35$ & 17 & 34.00 & 15 & 30.00 & \\
\hline $36-45$ & 14 & 28.00 & 11 & 22.00 & \\
\hline $46-55$ & 10 & 20.00 & 09 & 18.00 & \\
\hline$>55$ & 04 & 8.00 & 07 & 14.00 & \\
\hline Total & 50 & 100.0 & 50 & 100.0 & \\
\hline Mean $\pm S D$ & \multicolumn{2}{|c|}{$38.7 \pm 5.50$} & \multicolumn{2}{|c|}{$38.9 \pm 5.47$} & \\
\hline
\end{tabular}

Sex distribution: There were $65(65.00 \%)$ male subjects and 35 (35.00\%) female subjects. In group I (control), 34 (68.00\%) were male and 16 (32.00\%) were female. In group II (case), 31 $(62.00 \%)$ were male and $19(38.00 \%)$ were female. The sex distribution of two groups is presented in Table 02.

Table 02: Sex distribution of subjects

\begin{tabular}{|l|l|l|}
\hline Sex & Control (group I) & Case (group II) \\
\hline Male $(65)$ & $34(68.00 \%)$ & $31(62.00 \%)$ \\
\hline Female $(35)$ & $16(32.00 \%)$ & $19(38.00 \%)$ \\
\hline Total & 50 & 50 \\
\hline
\end{tabular}

Body mass index (BMI) of the subjects: The mean value with \pm SD of body mass index (BMI) in group I (Control) was $22.99 \pm 1.18$ and that in group II (Case) was $17.82 \pm 1.20$. Unpaired t-test was done between group I and group II. Mean values of BMI shows significant difference between group I (control) and group II (case). ( $p<0.001)$.

Table 03: Comparison of mean BMI in the study population

\begin{tabular}{|l|l|l|l|}
\hline Variable & $\begin{array}{l}\text { Group I (control) } \\
\text { Mean } \pm \text { SD }\end{array}$ & $\begin{array}{l}\text { Group II (Case) } \\
\text { Mean } \pm \text { SD }\end{array}$ & p-value \\
\hline $\mathrm{BMI}\left(\mathrm{Kg} / \mathrm{m}^{2}\right)$ & $22.99 \pm 1.18$ & $17.82 \pm 1.20$ & $0.001^{* *}$ \\
\hline
\end{tabular}

Serum zinc: The study revealed that mean serum zinc level was lower in case group compared to control group. The mean \pm SD values of serum zinc were $93.96 \pm 10.04 \mu \mathrm{g} / \mathrm{dl}$ and $72.84 \pm 7.73$ $\mu \mathrm{g} / \mathrm{dl}$ in control and case group respectively. The analysis showed that, the difference in mean serum zinc levels between two groups was highly significant $(p<0.001)$. Analysis of mean serum zinc levels is presented in Table 04. 
Table 04: Comparison of mean serum zinc levels in the study population

\begin{tabular}{|l|l|l|l|}
\hline Variable & $\begin{array}{l}\text { Control } \\
\text { Mean } \pm \text { SD }\end{array}$ & $\begin{array}{l}\text { Case } \\
\text { Mean } \pm S D\end{array}$ & -value \\
\hline $\begin{array}{l}\text { Serum zinc } \\
(\mu \mathrm{g} / \mathrm{dl})\end{array}$ & $93.96 \pm 10.04$ & $72.84 \pm 7.73$ & $0.001^{* *}$ \\
\hline
\end{tabular}

Serum copper: The study revealed that mean serum copper level was higher in case group as compared with control group. The mean \pm SD values of serum copper were $111.81 \pm 21.26 \mu \mathrm{g} / \mathrm{dl}$ and $125.99 \pm 27.93 \mu \mathrm{g} / \mathrm{dl}$ in control and case group respectively. The analysis showed that, the difference in mean serum copper levels between two groups was highly significant $(p<0.001)$. Analysis of mean serum copper levels is presented in Table 05.

Table 05: Comparison of mean serum copper levels in the study population

\begin{tabular}{|l|l|l|l|}
\hline Variable & $\begin{array}{l}\text { Control } \\
\text { Mean } \pm S D\end{array}$ & $\begin{array}{l}\text { Case } \\
\text { Mean } \pm S D\end{array}$ & $p$-value \\
\hline $\begin{array}{l}\text { Serum copper } \\
(\mu \mathrm{g} / \mathrm{dl})\end{array}$ & $111.81 \pm 21.26$ & $125.99 \pm 27.93$ & $0.001^{* *}$ \\
\hline
\end{tabular}

\section{Discussion}

The age of the subjects of the study ranged from 18-65 years. Maximum patients (30\%) of PTB belonged to 26-35 years of age. In case of sex distribution, males $(68.00 \%)$ were predominant. The mean BMl of case group was significantly lower compared with control group. It is not still clear that low BMI contributes for TB or TB contributes decrease in BMI. In this study, the BMI at the time of diagnosis was found severely low for some study subjects and for others were near normal but not a healthy BMI. Some study showed that there was significant variation in BMI of PTB patients - mostly decreased BMI below normal. ${ }^{14}$

In the present study there is highly significant decrease of serum zinc concentration in case group compared with control group that showed similarity with Sharda and Bhandari., Karyadiet et al., and Koyanagi et al,.8,15,16 Redistribution of zinc in the liver plays an important role and Metallothionein that bind with zinc and draw away from circulating pool done by IL-1 that explain MTB use zinc for growth and reproduction. ${ }^{17,18}$ Low zinc level decreases the production of tumor necrosis factor-a (TNF-a) and gamma interferon (INF- $\gamma$ ) from peripheral mononuclear cells that decrease the phagocytic activity, humoral immunity and cell mediated immunity. As a result, there is decreased number of circulating T-cell. These mechanisms increase the susceptibility to MTB infection and also reactivation of TB. ${ }^{19}$ Oluboya et al., showed that PTB affected the metabolism of trace elements with significant decreased level of serum zinc. ${ }^{20}$ Other studies from India and Japan showed that there was increased mean serum zinc concentration in PTB patients. ${ }^{21,22}$

In the present study there was significant increase of serum copper level in case group compared with control group that showed similarity with Bogden et al., Ahmad et al., Ciftci et al., ${ }^{23-25}$ In PTB there is nonspecific rise of ceruloplasmin- copper binding protein that might have role in increased serum copper level. ${ }^{23}$ Neyrolles et al., showed that copper redistribution and mobilization reported as a key factor in immune response in PTB infection. ${ }^{26}$ So increased serum copper level denotes host inflammatory response against infection or inflammatory condition like TB. ${ }^{27}$ However, Edem et al., showed decreased serum copper level in PTB patients due to utilization by macrophages and mycobacterium. ${ }^{28}$ Another report showed that mycobacteria require copper for survival. ${ }^{29}$ 


\section{Conclusion}

Pulmonary tuberculosis (PTB) is still one of the leading causes of death. There was significant decrease of BMI that indicates malnutrition of the PTB patients. Further study may be needed to find out whether MTB causes malnutrition or malnutrition predisposes to TB infection. Various micronutrients have role in body defense mechanism. In this study there was significant decrease of serum zinc level and significant rise of serum copper level. So, every PTB patient needs further evaluation of micronutrients status to find out their correlation with MTB.

\section{Acknowledgement}

We would like to thank all the teachers and staff of the department of Biochemistry, Mymensingh Medical College for helping us through the research work.

\section{Conflict of interest Nothing to declare.}

\section{References}

1. Crofton J, Horne N, Miller F. Clinical Tuberculosis. 2nd ed. London \& Basingstoke: MacMillan Education; 1999.

2. Walker B, Colledge N, Ralston S, Penmen I. Davidson's principle and practice of medicine. 22nd ed. London: Elsevier,; 2014.

3. Copper A, Odle T, Frey R. The Gale encyclopedia of alternative medicine. Choice Reviews Online. 2005;42(11) :42-6226-42-6226.

4. WHO 2008, 'Global tuberculosis control: surveillance, planning, financing 2008', World Health Organization, Geneva. 2021.

5. Yuniastutti A. 'The role and characteristic of antioxidant for redox homeostasis control system in Mycobacterium tuberculosis. International Journal of microbiology. 2012;19(03):416-422.
6. World Tuberculosis Day 2017 [Internet]. Who.int. 2017 [cited 26 August 2021]. Available from: https://www.who.int/ bangladesh/news/detail/23-03-2017-worl d-tuberculosis-day-2017

7. World Tuberculosis Day Today: Not all upazilas have screening facilities [Internet]. The Daily Star. 2016 [cited 26 August 2021]. Available from: https:// www.thedailystar.net/backpage/news/wo rld-tuberculosis-day-today-not-all-upazila s-have-screening-facilities-1719442

8. Karyadi E, Schultink W, Nelwan R, Gross R, Amin Z, Dolmans W et al. Poor Micronutrient Status of Active Pulmonary Tuberculosis Patients in Indonesia. The Journal of Nutrition. 2000;130 (12):2 953- 2958.

9. Beck F, Prasad A, Kaplan J, Fitzgerald J, Brewer G. Changes in cytokine production and $\mathrm{T}$ cell subpopulations in experimentally induced zinc-deficient humans. American Journal of Physiology-Endocrinology and Metabolism. 1997;272(6):E1002-E1007.

10. Uauy R, Olivares M, Gonzalez M. Essentiality of copper in humans. The American Journal of Clinical Nutrition. 1998;67(5):952S-959S.

11. Bremner I. Manifestations of copper excess. The American Journal of Clinical Nutrition. 1998;67(5):1069S-1073S.

12. Makino K, Mossoba M, Riesz $P$. Chemical effects of ultrasound on aqueous solutions. Evidence for hydroxyl and hydrogen free radicals (.cntdot.OH and .cntdot.H) by spin trapping. Journal of the American Chemical Society. 1982;104 (12):3537- 3539.

13. Abe A, Yamashita S, Noma A. Sensitive, direct colorimetric assay for copper in serum. Clinical Chemistry. 1989;35(4):552-554.

14. Ko Y, Kim C, Park Y, Mo E, Moon J. Changes in Nutritional Status in Pulmonary Tuberculosis: Longitudinal Changes in BMI According to Acid-Fast Bacilli Smear Positivity. Journal of Clinical Medicine. 2020;9(12):4082. 
15. Sharda B, Bhandari B. Serum zinc in childhood pulmonary tuberculosis. Indian Paediatr. 1997;14:195-196.

16. Koyanagi A, Kuffó D, Gresely L, Shenkin A, Cuevas L. Relationships between serum concentrations of C-reactive protein and micronutrients, in patients with tuberculosis. Annals of Tropical Medicine \& Parasitology. 2004;98(4):391-399.

17. ROFE A, PHILCOX J, COYLE P. Trace metal, acute phase and metabolic response to endotoxin in metallothionein-null mice. Biochemical Journal. 1996;314(3):793-797.

18. Canneva F, Branzoni M, Riccardi G, Provvedi R, Milano A. Rv2358 and FurB: Two Transcriptional Regulators from Mycobacterium tuberculosis Which Respond to Zinc. Journal of Bacteriology. 2005;187(16):5837-5840.

19. Mayordomo L, Marenco J, Gomez-Mateos J, Rejon E. Pulmonary miliary tuberculosis in a patient with anti-TNF-alpha treatment. Scandinavian Journal of Rheumatology. 2002;31(1):44-45.

20. Oluboyo $P$, Erasmus $R$. The significance of glucose intolerance in pulmonary tuberculosis. Tubercle. 1990;71(2):135-138.

21. Ramakrishnan $K$, Shenbagarathai $R$, Kavitha K, Uma A, Balasubramanian R, Thirumalaikoludsubramanian P. Serum Zinc and Albumin Levels in Pulmonary Tuberculosis Patients with or without HIV. Japanese Journal of Infectious Disease. 2008;3(61):202-204.

22. Kassu A, Yabutani T, Mahmud Z, Mohammad A, Nguyen N, Huong B et al. Alterations in serum levels of trace elements in tuberculosis and HIV infections. European Journal of Clinical Nutrition. 2005;60(5):580-586.
23. Bogden J, Kemp F, Han S, Li W, Bruening $\mathrm{K}$, Denny $\mathrm{T}$ et al. Status of selected nutrients and progression of human immunodeficiency virus type 1 infection. The American Journal of Clinical Nutrition. 2000;72(3):809-815.

24. Ahmad P, Grang R, Salahuddin A. Serum Zinc and Copper in Tuberculosis. Indian J Pediatr. 1985;22:786-788.

25. Ciftci T, Ciftci B, Yis O, Guney Y, Bilgihan A, Ogretensoy M. Changes in Serum Selenium, Copper, Zinc Levels and $\mathrm{Cu} / \mathrm{Zn}$ Ratio in Patients with Pulmonary Tuberculosis During Therapy. Biological Trace Element Research. 2003;95(1):65-72.

26. Neyrolles $O$, Wolschendorf $F$, Mitra A, Niederweis M. Mycobacteria, metals, and the macrophage. Immunological Reviews. 2015;264(1):249-263.

27. Moraes $\mathrm{M}$, Ramalho $\mathrm{D}$, Delogo $\mathrm{K}$, Miranda P, Mesquita E, de Melo Guedes de Oliveira $\mathrm{H}$ et al. Association of Serum Levels of Iron, Copper, and Zinc, and Inflammatory Markers with Bacteriological Sputum Conversion During Tuberculosis Treatment. Biological Trace Element Research. 2014;160(2):176-184.

28. Edem V, Ige $O$, Arinola $O$. Plasma vitamins and essential trace elements in newly diagnosed pulmonary tuberculosis patients and at different durations of anti-tuberculosis chemotherapy. Egyptian Journal of Chest Diseases and Tuberculosis. 2015;64(3):675-679.

29. Rowland J, Niederweis M. Resistance mechanisms of Mycobacterium tuberculosis against phagosomal copper overload. Tuberculosis. 